\title{
Upper Cretaceous planktic foraminiferal biostratigraphy
}

\author{
Marius Dan Georgescu \\ Department of Geoscience, University of Calgary, 2500 University Drive NW, Calgary, AB T2N 1N4, Canada
}

Received: June 2017; accepted September 2017

Available online 15 September 2017

DOI: https://doi.org/10.5038/1937-8602.61.1.1297

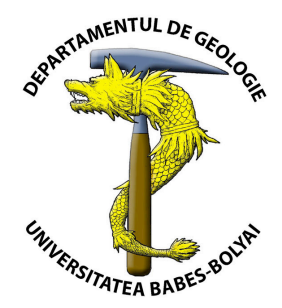

\begin{abstract}
A high-resolution biostratigraphical zonation based on planktic foraminifera is developed for the Upper Cretaceous. It consists of twenty-five biozones defined with the aid of serial and coiled planktic foraminiferal taxa and presents the highest resolution developed with planktic foraminifera for this Series. All the index species used in biozonation are part of the practical classification associated with the evolutionary classification. The new biozonation represents a first in using data directly derived from the Theory of Evolution and its evolutionary classification extension in an application of paleontology such as biostratigraphy. By this the Theory of Evolution becomes a direct provider of data in applied studies.
\end{abstract}

Keywords: Cretaceous, planktic foraminifera, biostratigraphy.

\section{INTRODUCTION}

Living and fossil organism classification is not unique. There are different classifications and methodologies that were developed in the past, and the first of which we know of is the classification of plants according to their uses preserved on the clay tablets in the library of Ashurbanipal at Nineveh, conventionally dated at 627 B.C. The first scientific classifications were produced at the end of Greek Classicism and beginnings of Hellenistic period for animals by Aristotle of Stagira (384 - 322 B.C.) and plants by his younger collaborator and successor Theophrastus of Eresos ( 371 - 286 B.c.). Concepts such as species, genus, essential characters, which were originally defined as part of metaphysics, date back from this period of scientific development and they echo to our days in what is known as Linnaean classification. The methodology of these early classifications considers organism grouping according to their degree of morphological resemblance appears directly derived from the human natural tendency to group similar organisms into larger categories. Linnaean classification that is the method used by most specialists today in grouping living and fossil organisms is of Aristotelian nature.

The birth of the Theory of Evolution happened with the publication of The Origin of Species by Darwin (1859). This work, which is a milestone in the history of mankind, prefigures the idea of a new classification method. It was noted by C.R. Darwin that one taxonomic unit of the "tree of life" includes features common with some of those of the ancestor (common ancestry) and newly developed ones that resulted from the divergent evolutionary process. Therefore, it is possible to define natural groupings of organisms if we can recognize the taxa in direct ancestor-descendant relationship. Ancestry plays a paramount role in the definition of natural groups, for it aims to eliminate the effects of nonevolutionary groupings due to the convergence morphologies generated through iterative and parallel evolution. The idea remained dormant for more than one century, until Mayr (1968) revisited it and provided it with a name: evolutionary classification. Noteworthy, the expression "evolutionary classification" occurs in some earlier works, in general attached to a Linnaean classification framework in which the taxa are linked through ancestor-descendant relationships. This author identified one paramount feature of this classification method, namely its a posteriori character: units are defined after the ancestor-descendant relationship is recognized, which leads to an improved assessment of the features used further in classification. But the method remained in theoretical state even after a more detailed analyse by Mayr and Ashlock (1991) ... something was missing.

Evolutionary classification was then resurrected in the study of Cretaceous planktic foraminifera that have at least one growth stage with chambers alternately added with respect to the growth axis (Georgescu, 2007a, b, 2009a) and extended rapidly on trochospiral taxa (Georgescu, 2009b, c). In circa one decade there was a tremendous number of innovations supported by high-resolution scanning electron microscope (SEM) observations and a relatively rich fossil record that frequently yielded well-preserved specimens: at first species were grouped into lineages that received formal status in classification, then species were abandoned in favour of the more accurate stages of morphological relative stability, different types of lineages were recognized according to their architecture, a new nomenclature system was applied, typification was abandoned, etc. Practically, all these developments were made possible by the newly developed capability to assess in the fossil record the morphological features resulted from common ancestry and the newly acquired ones as result of the evolutionary process. Application of the method at the scale of an entire group by Georgescu (2014a) showed significant errors in the biostratigraphical scales developed through units of Linnaean classification. As 
a result, the stratigraphical ranges of the lineages and different events recorded in each lineage evolution were tied to the classical stages and substages. This situation became acute when the newly developed method reached the stage in which evolutionary monographs can be produced. In the first work of this class it was clearly noted that the classical Linnaean units cannot be used for producing a biostratigraphical scheme capable of meeting the requirements of high resolution evolutionary framework (Georgescu, 2016), one observation that leads directly to the goal of this article, which is to develop a new Upper Cretaceous biostratigraphical framework of higher resolution based on the representatives of planktic foraminifera.

\section{RATIONALE}

Biostratigraphy is traditionally regarded by specialists as distinct from Theory of Evolution, and no evolutionary ideas were included up-to-date in the biostratigraphical zonations based on Cretaceous planktic foraminifera. There are also opinions that the development of an evolutionary perspective on the fossil record reduces the possibilities of development of more accurate biostratigraphical zonations; the main argument is represented by the difficulties in recognizing the earliest occurrence of one species, the most frequently used type of bioevent used in biostratigraphy in the last century. This perspective is highly detrimental for the specialists that use it tend to regard the species as morphologically stable, and such stability is presented as a sine qua non condition for biostratigraphical studies. But this leads to an understanding of the species closer to fixism and in this context is it easy to understand why specialists that adopted this methodology in their practice focus the attention on holotype and often consider species centred on holotype.

It was evident during the development of the evolutionary classification in Cretaceous planktic foraminifera that much of the attention was on high detail test features. This practice came in contradiction with the perspective of biostratigraphers that required a simpler method to produce data useful in stratigraphical interpretations. As a general observation, during development of the evolutionary classification I encountered an extreme opposition especially from those specialists that have a considerable number of articles in the field stratigraphy and especially biostratigraphy. The problem is not new and more than half century ago Wright (1950, p. 748) noted: "A phylogenetic approach draws attention to minor morphological differences by which the various stocks can be distinguished. Not to distinguish them, apart from all theoretical objections, deprives the stratigraphers of a useful tool."

The problem to introduce the data of evolutionary nature in biostratigraphy was stated several times in the past, in different forms. I present herein the perspective of Young (1960, p. 350): "To further summarize, the biostratigrapher must classify a rock continuum by means of a biological continuum, using a stratigraphic nomenclature and biologic nomenclature that were originally applied to a lot of unrelated, discontinuous entities. Darwin figuratively supplied us with the biological continuum, which we still classify by Linnaean nomenclature." Evolutionary classification in Cretaceous planktics was developed as part of the Darwinian Theory of
Evolution and resulted in the production of a vast amount of data, many of them not yet published. Such data are ready to be introduced now in biostratigraphical practice and the only question that remains is how. This is the first attempt, which will be improved as new and useful data will become available. By this the Theory of Evolution and evolutionary classification make a clear step towards applied studies, contradicting all the previous mentions in which their capability of providing practical results was questioned, and of which I will mention only that of Weller (1949, p. 683): "This movement of classification away from usefulness and practicality indicates that systematists consider phylogenetic classification to be an end in itself."

\section{BIOZONE BOUNDARY BIOEVENTS}

The concept of biozone used in the framework developed herein is that generally accepted in biostratigraphy, which defines it as the layer, group of layers or bodies of rocks situated between two bioevents; the corresponding time interval of a biozone is the biochronozone. Biozone and biochronozone are the fundamental units in biostratigraphy and biochronostratigraphy respectively. Two types of bioevents are used in the definition of these units, and they are given by the process of species evolution and extinction (Fig. 1). One species evolution can be also referred to as evolutionary occurrence, whereas no synonyms are used for extinction.

High accuracy data acquired during the development of the evolutionary classification in Cretaceous planktics showed that the process of one species evolution is a long one, which begins with sporadic occurrences of specimens in the ancestor species that prefigure the fully developed morphology that

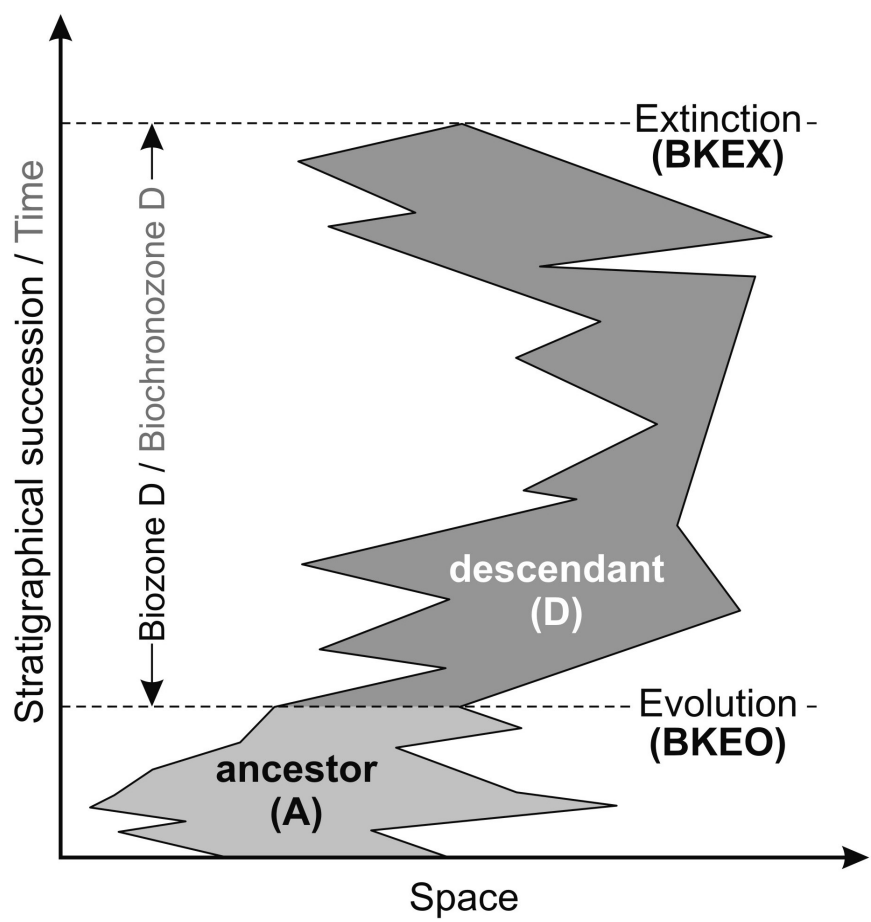

Fig. 1. Schematic representation of the distribution in space and time of a species (D), which descends from another one (A); the two species are linked through direct ancestor-descendant relationships. Abbreviation of the main bioevents related to species D: BKEO-best known evolutionary occurrence, BKEX-best known extinction event. 
will be achieved in the descendant species. It continues with the onset of the test morphology that occurs in the descendant, but specimens of the descendant that present features of the ancestor also occur and are more frequent in the lower portion of the stratigraphical range of the descendant. This contrasts with the models in which the species evolution is fast, such as punctuated equilibria (Eldredge and Gould, 1972) and punctuated gradualism (Kieser and Groencveld, 1985).

In fact, the occurrence of large number of specimens of the ancestor or descendant that morphologically resemble the other demonstrates the evolutionary continuum and was one of the main reasons to develop the evolutionary classification in this group, and the main reason to question the very existence of species. Consequently, the concept of species was removed and replaced in evolutionary classification by that of stage of morphological relative stability (SMRS), such entities are components of the fundamental units in this classification methodology, namely lineages. The morphological variability encountered before and after the onset of one descendant relatively stable morphology is a potential source of misinterpretations especially for those biostratigraphers that are not familiar with the evolutionary classification. By removing those specimens and retaining only the two main and relatively stable morphologies of the ancestor and descendant it is possible to recognize with a higher precision the stratigraphical level at which the onset of the descendant happens. These are entities used in the practical classification associated with the evolutionary classification, but there is a distinct loss of taxonomic resolution through the practice of removal of specimens with intermediary morphological features between ancestor and descendant (Georgescu, 2015). Notably, they are referred to as "species" and should not be confused with the evolutionary classification stages of morphological relative stability, which are morphologically broader.

In the fossil record the onset of the descendant species morphological features from the ancestor is the process of speciation, which in biostratigraphy marks the evolution or evolutionary occurrence bioevent. One taxonomic unit ceases to occur in the fossil record once it became extinct, and the process of extinction marks its highest occurrence in the fossil and stratigraphical record. The stratigraphical interval between the evolution and extinction of one taxonomic unit represents the stratigraphical range of the respective unit. Identifying the stratigraphical range of one taxonomic unit highly depends mainly of (1) fossilization bias, (2) availability of rocks and sediments that embed it, (3) availability of preparation techniques to make the specimens of the respective unit suitable for an accurate study, and (4) degree of our knowledge on the respective unit or higher unit in which it is included. These processes and especially (1) and (2) strongly impact our capabilities to recognize the processes of evolution and extinction in the fossil and stratigraphical record. For this reason, in the classical biostratigraphical terminology were and often still are used the concepts of first occurrence (FO) and last occurrence (LO) for evolution and extinction respectively. The succession FO to LO is given according to the stratigraphical order, which is from the oldest to the youngest. An alternative terminology of similar precision was subsequently developed in the oil industry and applied to biostratigraphical data collected from boreholes: FDO/
LDO (first downhole occurrence/last downhole occurrence). The classical terminology was in use for more than fifty years until alternatives with a vaguer scientific content started to be proposed and eventually used by many scientists: FAD/ LAD (first appearance datum/last appearance datum) and FOD/LOD (first occurrence datum/last occurrence datum); the vaguest terminology is that of $\mathrm{LO} / \mathrm{HO}$ (lowest occurrence/ highest occurrence) for it can be used equally in young Earth creationism.

A new terminology is herein applied to accommodate the level of precision achieved in evolutionary classification. The two bioevents that define one taxonomic unit evolution and extinction respectively: BKEO (Best Known Evolutionary Occurrence) and BKEX (Best Known Extinction). This terminology has certain advantages when compared to the previous ones but the most important one is that it includes the Darwinian evolution that happens only in geological time and therefore, includes in unified form the two major concepts used in biostratigraphy.

\section{GENERA IN THE PRACTICAL CLASSIFICATION ASSOCIATED WITH EVOLUTIONARY CLASSIFICATION}

It was noted by Caron (1985) that the species level is of paramount importance in Cretaceous planktic foraminiferal biostratigraphy. The genus concept as used at that time was quite broad and yielded few usable bioevents of which many proved questionable. However, defining groupings of species according to morphological resemblance was a constant preoccupation of the taxonomists and biostratigraphers in the last half century. The main goal that fueled these studies was the correlation between taxonomy and classification on one hand and patterns observed in the Cretaceous planktic foraminiferal evolution (e.g., iterative evolution) on the other. Steps forward have been made in this direction but ultimately this stream in group's research was significantly slowed down and ultimately abandoned probably because there were too many genera that needed formalization. In addition, the problems became even more complex when in the early phase of development of the evolutionary classification species started to be grouped into lineages rather than genera and moreover, various kinds of lineages were described according to their architecture (Georgescu, 2010, 2013a, 2014b).

These are some of the developments that led Georgescu (2015) to separate between the evolutionary classification as main framework and practical classification associated with it that has the purpose of being used in applied studies. It was mentioned with this occasion that in this practical classification the groupings of species into genera do not include the effects of the iterative evolution. For this reason, fewer genera are acknowledged when compared to the classical Linnaean classification for the representatives of this group (Fig. 2). In contrast to it, the classical Linnaean classification framework acknowledges in part the effects of iterative evolution and in this phase of development can be characterized as hybrid: neither evolutionary nor practical. The genera defined for the practical classification associated with the evolutionary classification are thoroughly used in the development of the actual biostratigraphical framework. 


\begin{tabular}{|c|c|}
\hline $\begin{array}{c}\text { Practical classification } \\
\text { associated with evolutionary } \\
\text { classification }\left({ }^{*}\right)\end{array}$ & $\begin{array}{c}\text { Classical Linnaean } \\
\text { classification }(* *)\end{array}$ \\
\hline \multirow{2}{*}{ Heterohelix } & Heterohelix \\
\hline & Gublerina (partly) \\
\hline Sigalia & Sigalia \\
\hline \multirow{2}{*}{ Ventilabrella } & Ventilabrella \\
\hline & Pseudoguembelina (partly) \\
\hline \multirow{2}{*}{ Pseudoguembelina } & Pseudoguembelina (partly) \\
\hline & Huberella \\
\hline Gublerina & Gublerina (partly) \\
\hline Hedbergella & Hedbergella \\
\hline \multirow{2}{*}{ Praeglobotruncana } & Praeglobotruncana \\
\hline & Globotruncanella \\
\hline \multirow{3}{*}{ Rotalipora } & Rotalipora \\
\hline & Thalmanninella \\
\hline & Parathalmanninella \\
\hline \multirow{2}{*}{ Concavatotruncana } & Concavatotruncana \\
\hline & Dicarinella (partly) \\
\hline \multirow{3}{*}{ Globotruncana } & Globotruncana \\
\hline & Falsotruncana \\
\hline & Abathomphalus \\
\hline \multirow{2}{*}{ Globotruncanita } & Globotruncanita \\
\hline & Bollitruncana \\
\hline Contusotruncana & Contusotruncana \\
\hline Radotruncana & Radotruncana \\
\hline \multirow{3}{*}{ Bucherina } & Bucherina \\
\hline & Gansserina \\
\hline & Helvetoglobotruncana \\
\hline
\end{tabular}

Fig. 2. Correspondence between the genera used in the practical classification associated with evolutionary classification and traditional Linnaean classification. (*)-after Georgescu (2015), (**) after Loeblich and Tappan (1987) with additional genera from Korchagin (2003) and Lipson-Benitah (2008).

\section{BRIEF HISTORICAL ACCOUNT ON UPPER CRETACEOUS PLANKTIC FORAMINIFERAL BIOSTRATIGRAPHY}

Planktic foraminiferal biostratigraphy began soon after the description of the first species, when Bailey in Hitchcock (1843) prefigured that heterohelicid species can be used for intercontinental correlation (Georgescu, 2013b). It continued with a period of over one century in which different authors made remarks on the stratigraphical distribution of various species but without proposing a framework consisting of biozones. The beginnings of the modern Cretaceous planktic foraminiferal biostratigraphy can be considered with the first biostratigraphical frameworks proposed by Brönnimann (1952), Sigal (1955) and Dalbiez (1955) and probably the evolution chart of globotruncanid species by Bolli (1951) might have played a key role in the definition of the earliest biozones by Brönnimann (1952). Two works of synthesis that present the advances in the "pioneering period" are those of Bolli (1960, 1966). Several biostratigraphical frameworks were proposed in the next years (Bandy, 1967; Pessagno, 1967; Douglas, 1969; Barr, 1972) but the focus shifted towards clarification of the stratigraphical position of biozones and boundaries.

Constant contributions during the early years of the Deep Sea Drilling Project that begun in 1969 together with the review of the Cretaceous taxa under the auspices of The European Working Group on Planktonic Foraminifera led to the development of a biostratigraphical framework, which will prove highly influential in the next decades (Robaszynski et al., 1979; Robaszynski et al., 1984; Caron, 1985). A distinct biostratigraphical framework using heterohelicid taxa was given by Nederbragt (1990) in her Ph.D. Thesis, but will be brought in the public domain by Robaszynski and Caron (1995). These data started to be calibrated to other stratigraphical scales resulting in a framework that remained stable for a nearly fifteen years (Premoli Silva and Sliter, 1994; Robaszynski and Caron, 1995). They were incorporated in The Geological Time Sale 2004 and could be used successfully in the initial period of development of the new evolutionary classification.

\section{MATERIAL AND PREVIOUS STUDIES}

Most of the fossil assemblages used in the construction of the new planktic foraminiferal biostratigraphy for the Upper Cretaceous Series were collected from ten Deep Sea Drilling Project/Ocean Drilling program (DSDP/ODP) boreholes (Fig. 3). They can be grouped into three distinct geographical regions: Atlantic Ocean (DSDP Sites 95, 150 and 370, ODP Hole 1050C and ODP Leg 174AX), Pacific Ocean (DSDP Sites 305 and 463) and Indian Ocean (ODP Holes 761B, 762C and 763B). Different stratigraphical intervals were investigated at each of these locations. They provide an excellent coverage for all the six stages of the Upper Cretaceous: Cenomanian (5 sections), Turonian (6 sections), Coniacian (4 sections), Santonian (6 sections), Campanian (7 sections) and Maastrichtian (5 sections) (Fig. 4).

Foraminiferal assemblages of the ten sections were extensively analyzed and different phases of the study were published during 2006-2016. These studies focused on multiple aspects of the planktic foraminiferal assemblages, which include taxonomy, classification, evolution, biostratigraphy and paleobathymetry. There were studies focused on a certain group [e.g., schackoinids by Georgescu (2012a), pseudotextulariids by Georgescu (2014c), rotaliporids by Georgescu (2016), etc.] or multiple groups were investigated on the same time [e.g., review of the Cretaceous planktic in the C.G. Ehrenberg Collection by Georgescu (2013a), development of the evolutionary classification nomenclature by Georgescu $(2014 a)$, etc]. All these studies provided a rich and welldocumented basis for the development of a biostratigraphy that uses units of the evolutionary classification. The taxa at each site were extensively studied with the aid of the SEM, which resulted in high-resolution interpretations.

In the initial phases, the biostratigraphical frameworks used were those of Caron (1985), Robaszynski and Caron (1995) and that of The Geological Time Scale 2004. The modifications apparent in the planktic foraminiferal biozone succession of The Geological Time Scale 2012 determined a change in the perspective of this topic, as the reduction in the scientific quality when compared with the previous works became evident. As a result, a laborious work of identification of new biozones had started (Georgescu, 2012b; Georgescu et al., 2013; Georgescu and Sawyer, 2013; Georgescu, 2014). The biostratigraphy at each site was repeated for accuracy at least three times in addition to the usual study or studies 


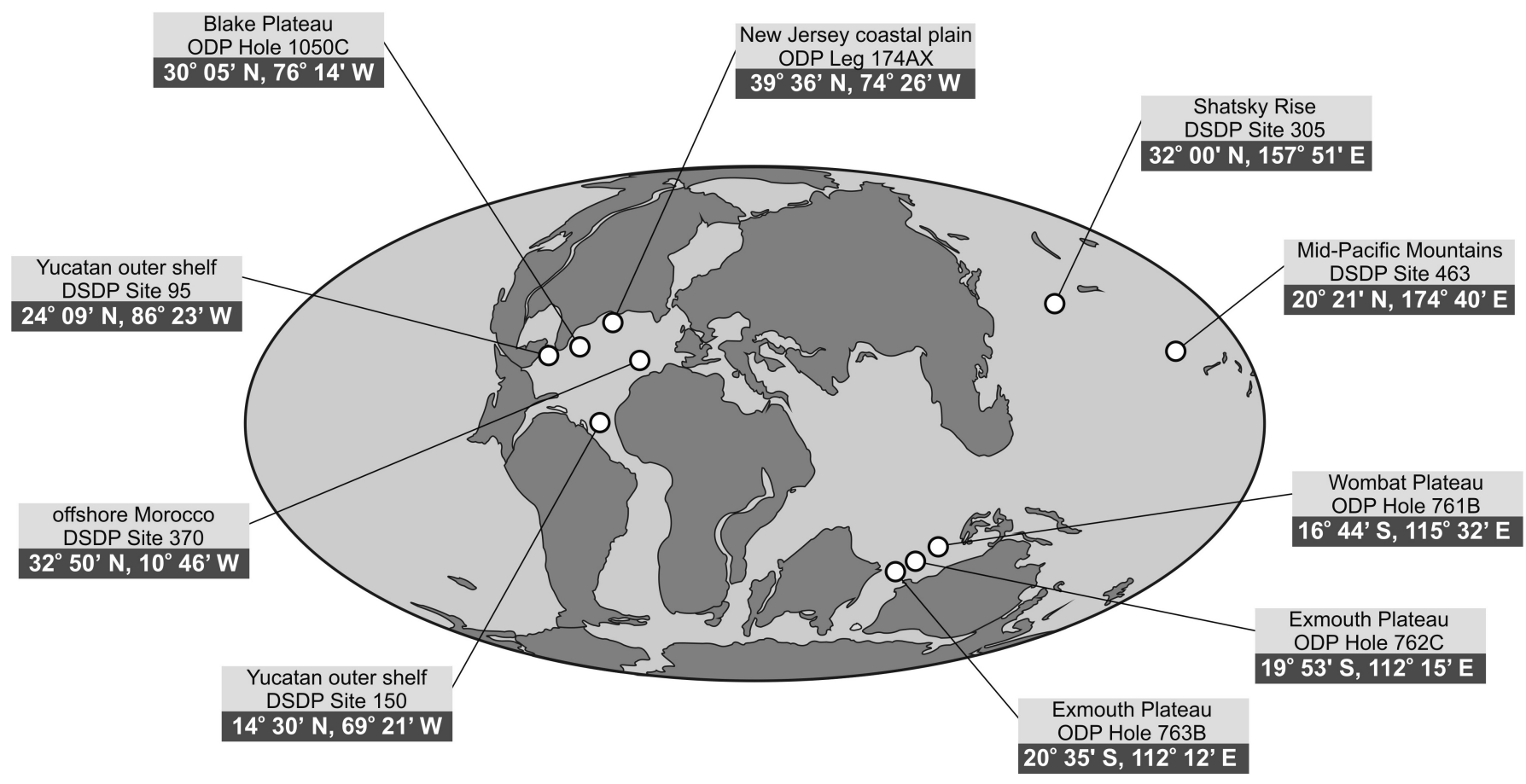

Fig. 3. Geographical location of the ten boreholes that provided most of the material used in this study. Base map after Hays et al. (1999).

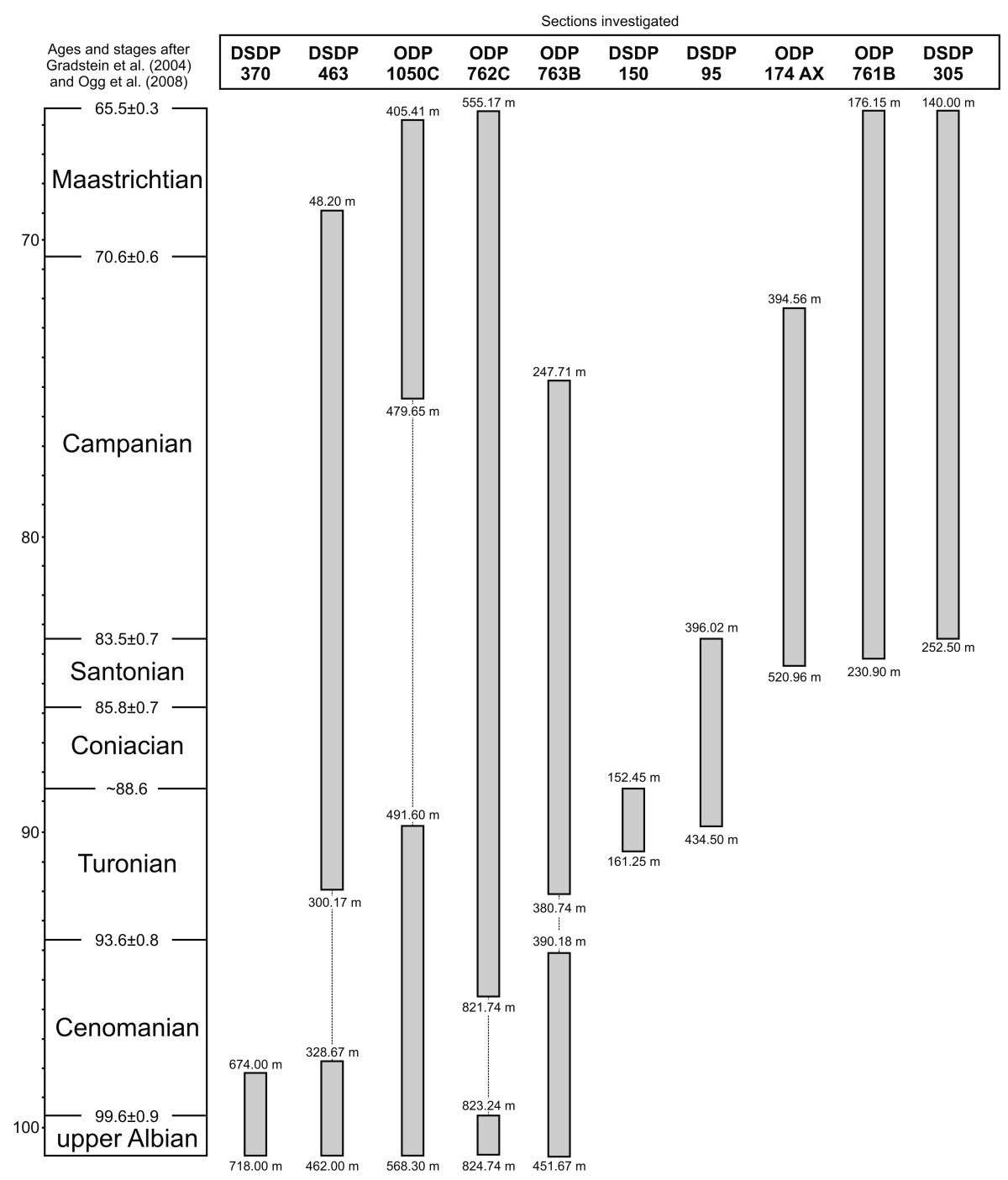

Fig. 4. Stratigraphical intervals covered in the ten DSDP/ODP boreholes that provided most of the material used in this study. 
for each of the published article. With the development of the practical classification associated with the evolutionary classification by Georgescu (2015) it was achieved a new stage that prepared in great proportion biostratigraphical framework presented herein, in addition to the methodology of linking the evolutionary and applied studies: all the planktic foraminiferal species were reviewed in evolutionary classification and their stratigraphical ranges re-documented.

Additional material came from other locations worldwide (inland and offshore) and each set of samples or collection material helped in clarifying various aspects of this study. At least in part they were published in more than thirty articles related to evolutionary classification and "ultrastructure revolution" I published in the last decade. One dataset cannot pass without a special mention and this is the material from the Romanian sector of the Western Black Sea Basin I studied for the Ph.D. Thesis (Georgescu, 1995, 1996, 2000, 2003), which represented a solid foundation for the development of fundamental and applied studies.

\section{BIOZONE DEFINITIONS}

A presentation of the biozones used in the new biostratigraphical framework of the Upper Cretaceous based on planktic foraminifera is given in this section. Biozones are presented in stratigraphical order (Fig. 5). The stratigraphical interval encompassed by the present framework is of latest Albian-Maastrichtian age because the lowermost biozone extends below the Lower/Upper Cretaceous boundary. Stratigraphical ranges of the index species, which are paramount in the biozone definitions are also provided (Fig. 6).

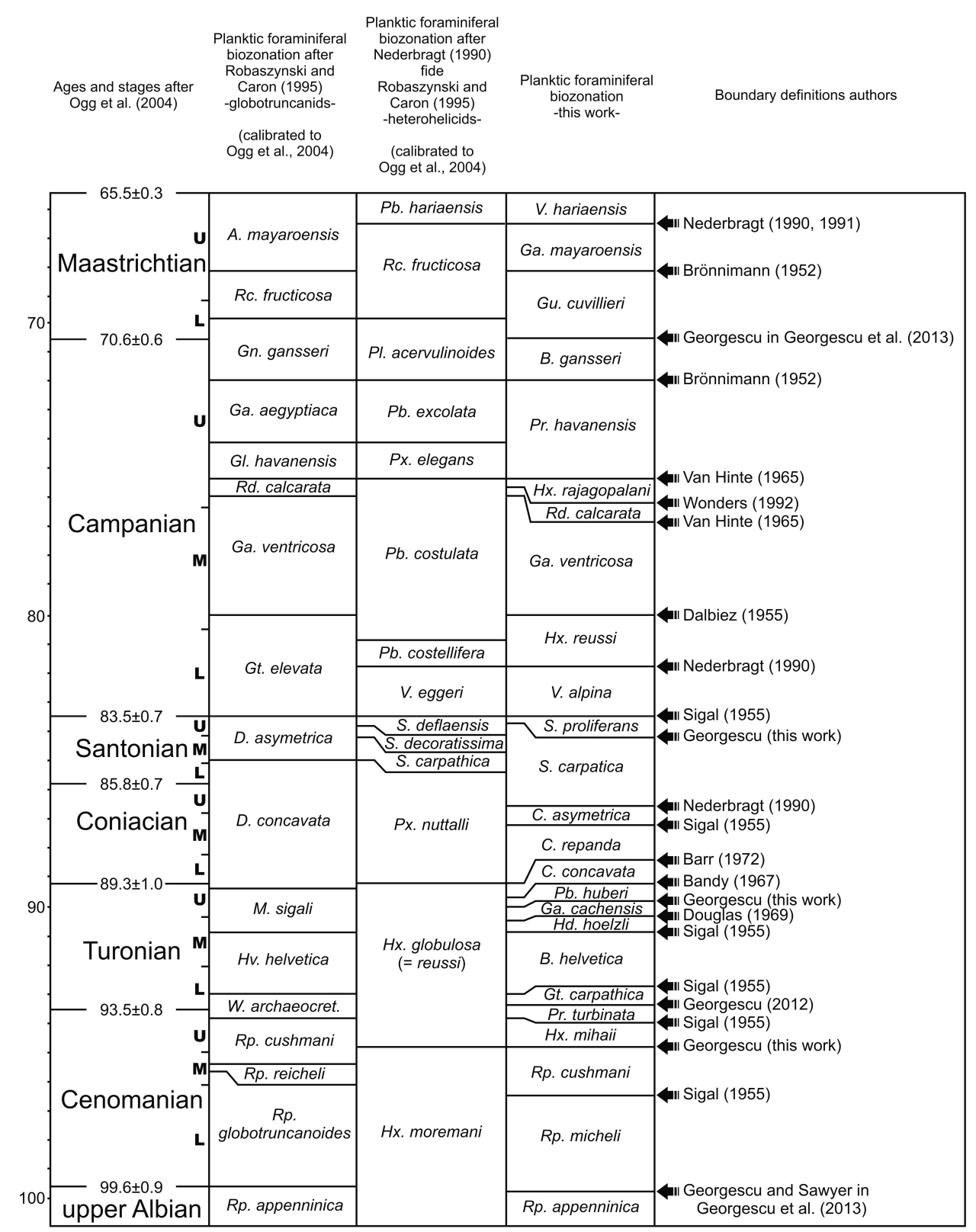

Fig. 5. Biostratigraphical zonation developed herein and correlation with that of Robaszynski and Caron (1995), which was adopted in The Geologic Time Scale 2004. Substages acronyms: L-lower, M-middle, U-upper. Genera abbreviations: A-Abathomphalus, B-Bucherina, $C$-Concavatotruncana, D-Dicarinella, Ga-Globotruncana, Gl-Globotruncanella, Gn-Gansserina, Gt-Globotruncanita, Gu-Gublerina, HdHedbergella, $H v$-Helvetoglobotruncana, $H x$-Heterohelix, $M$-Marginotruncana, $P b$-Pseudoguembelina, $P l$-Planoglobulina, $P r$-Praeglobotruncana, $P x$-Pseudotextularia, $R c$-Racemiguembelina, $R d$-Radotruncana, $R p$-Rotalipora, $S$-Sigalia, $V$-Ventilabrella, and $W$-Whiteinella. 


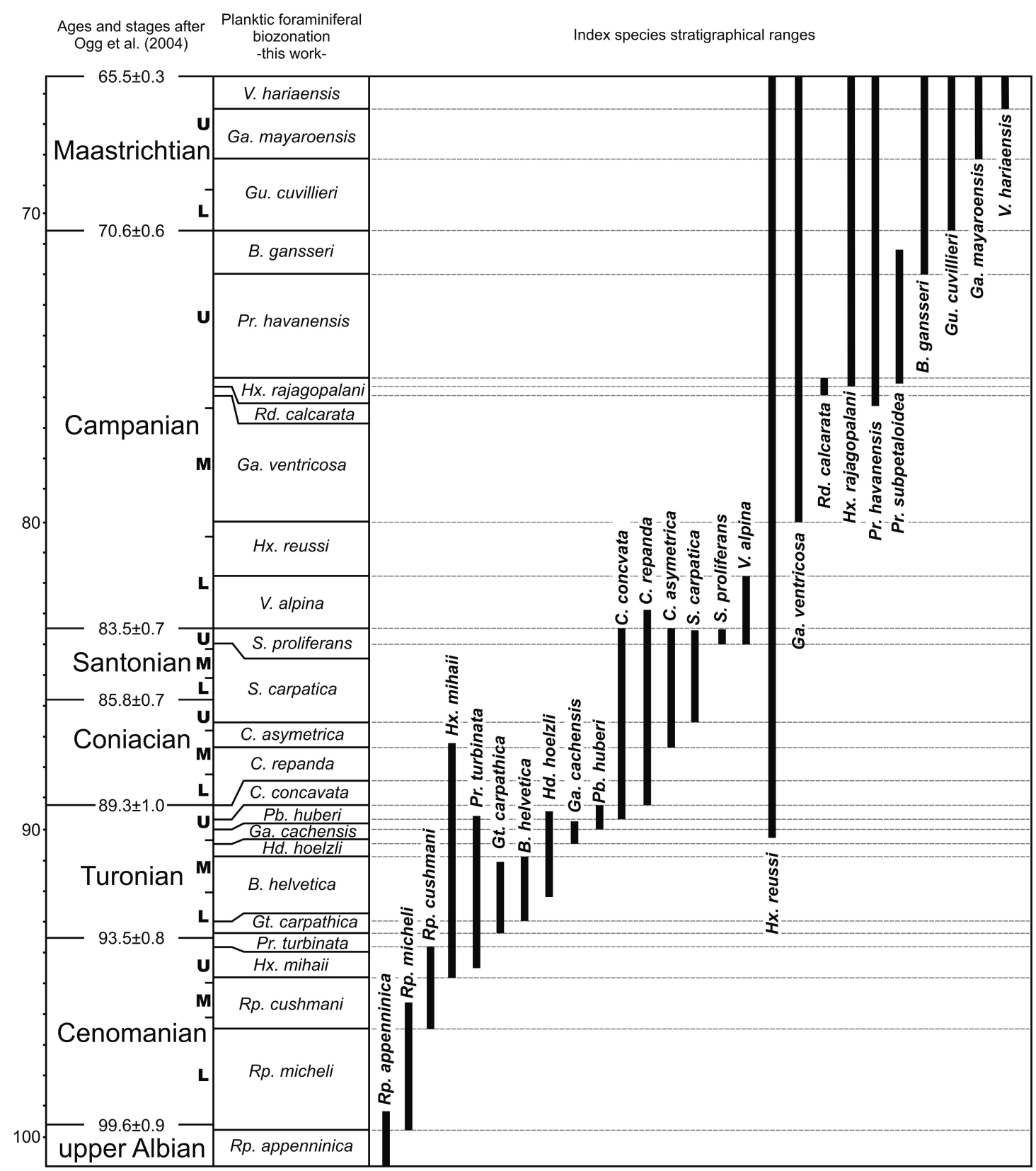

Fig. 6. Stratigraphical ranges of the index species used in the newly developed biostratigraphical zonation. Genera abbreviations: A-Abathomphalus, B-Bucherina, $C$-Concavatotruncana, $G a$-Globotruncana, $G t$-Globotruncanita, $G u$-Gublerina, $H d$-Hedbergella, $H x$-Heterohelix, $P b$-Pseudoguembelina, $P r$-Praeglobotruncana, $R d$-Radotruncana, $R p$ Rotalipora, $S$-Sigalia, and $V$-Ventilabrella.

\section{Rotalipora micheli Biozone}

- Age. Latest Albian-early Early Cenomanian.

- Definition. Stratigraphical interval from the BKEO of the index species to the BKEO of $R$. cushmani.

- Type. Interval Biozone.

- Comments (1). The BKEO of $R$. micheli from the doublekeeled planispiral Bannerina banneri was demonstrated by Georgescu and Sawyer in Georgescu et al. (2013). The earliest representatives of $R$. micheli present numerous chambers in the final whorl and Neagu (2005) erected the species $R$. moesiana mainly based on this feature; notably, this species was included in the synonymy of $R$. micheli in the evolutionary monograph on the rotaliporid planktic foraminifera (Georgescu, 2016). One specimen with double-keeled periphery was illustrated in the original report of this species by Sacal and Debourle
(1957). Specimens with fewer chambers in the final whorl are known from higher stratigraphical levels within the range of this species.

- Comments (2). A planktic foraminiferal marker for the Albian/Cenomanian boundary could not be recognized in this study. In the past, the species Rotalipora globotruncanoides was used to define this boundary (Robaszynski and Caron, 1995) and this definition was accepted by many authors afterwards. In evolutionary classification, it was shown that three species of the same directional lineage evolved in a brief period in the terminal Albian, namely in the upper part of the $R$. appenninica biozone, which in evolutionary succession are $R$. tehamaensis- $R$. brotzeni- $R$. globotruncanoides (Georgescu, 2016). Accordingly, a multitude of specimens with morphological features intermediary between these 
taxa occur in the rotaliporid assemblages below and above the Albian/Cenomanian boundary. The claim that specimens with the morphological features of the holotype of $R$. globotruncanoides occur precisely at the Albian/Cenomanian boundary could not be substantiated with relevant illustrations; this is supported by the presentation of this aspect in The Geological Time Scale 2012, where a specimen of $R$. globotruncanoides from outside the type section was used to illustrate the species at this crucial locality (Ogg and Hinnov, 2012).

\section{Rotalipora cushmani Biozone}

- Age. Late Early Cenomanian-early Late Cenomanian.

- Definition. Stratigraphical interval between the BKEO if the index species and BKEO of Heterohelix mihaii.

- Type. Interval Biozone.

- Comments (1). The occurrence of the index species in the Cenomanian was noted by many authors starting with Sigal (1955) and there is no other Late Cretaceous planktic foraminiferal biozone in which its definition to be more gradual. Probably the complete formalization of this biostratigraphical unit should be considered with the work of Pessagno (1967), but this is one aspect that requires further discussion.

- Comments (2). The evolution from the globularchambered Hedbergella to the single-keeled taxon Rotalipora was prefigured by Brönnimann and Brown (1956) but not demonstrated until the development of evolutionary classification. Georgescu (2016) defined the directional lineage in which the gradual transition from Hedbergella to R. cushmani; in the upper portion of this lineage the species evolutionary succession is as follows: $R$. praemontsalvensis- $R$. thomei- $R$. cushmani and notably, the rotaliporid test architecture that includes one robust peripheral keel is completely developed in the last two species. The first occurrence of $R$. cushmani is herein redefined according to the revision of the species $R$. montsalvensis, which was described by Mornod (1949). Rotalipora montsalvensis, was considered morphologically close to R. cushmani of which it differs mainly in the less developed keel and weaker ornamentation. The restudy of the type section by Caron (1976) resulted in a definition of a neotype for this species, which was later abandoned with the re-discovery and re-illustration of the holotype by Caron and Spezaferri (2006). The two articles are convergent in showing specimens in poor state of preservation. Therefore, $R$. montsalvensis was considered a junior synonym of $R$. cushmani by Georgescu (2016); according to this interpretation $R$. montsalvensis is a collection of specimens with weaker peripheral keel and ornamentation, or in poor state of preservation, which fit in the range of variability of $R$. cushmani. This has a paramount effect on the "standard zonation" and biostratigraphical frameworks of The Geological Time Scale 2004 and 2012 because the BKEO of $R$. cushmani, which was considered the index for the late Cenomanian occurs at a lower stratigraphical level than that of $R$. reicheli, the index of the middle Cenomanian. This new interpretation in which the BKEO of $R$. reicheli is after that of $R$. cushmani is consistent with rotaliporid evolution succession of events (Georgescu, 2016).

\section{Heterohelix mihaii Biozone}

- Age. Late Cenomanian.

- Definition. Stratigraphical interval between the BKEO of the index species and BKEX of Rotalipora cushmani.

- Type. Interval Biozone.

- Comments (1). The BKEO of the index species is situated about the half of the stratigraphical range of $R$. cushmani. It is a species recorded worldwide in the Late Cenomanian, occasionally with abundant occurrences, which makes this species an ideal index.

- Comments (2). Heterohelix mihaii was often confused for H. globulosa, a globular-chambered species described by Ehrenberg (1838) based on juvenile specimens. The status of $H$. globulosa as synonym of $H$. striata of SantonianMaastrichtian age was demonstrated after the restudy of the original material from the Ehrenberg Collection at the Museum of Natural Sciences of Berlin (Georgescu, 2013a). This came in contradiction with the traditional view on $H$. globulosa to which were assigned globularchambered specimens with the chamber surface ornamented with thin costae; smooth-chamber specimens were never illustrated using the highly-objective scanning electron microscopy (SEM) technique. Heterohelix mihaii has some morphological resemblances with $H$. striata, but belongs to a different lineage that evolved in the late Cenomanian from the stem of the heterohelicid planktic foraminifera (Georgescu in Georgescu et al., 2013; Georgescu, 2014a).

\section{Praeglobotruncana turbinata Biozone}

- Age. Latest Cenomanian-earliest Turonian.

- Definition. Stratigraphical interval with the index species from the BKEX of Rotalipora cushmani to the BKEO of Globotruncanita carpathica.

- Type. Partial Taxon Range Biozone.

- Comments (1). Praeglobotruncana turbinata presents worldwide distribution and frequently abundant occurrences shortly after the BKEO, which contribute to its designation as index species for an interval that includes the Cenomanian/Turonian boundary. This boundary was included within the Whiteinella archaeocretacea Biozone in many works on Cretaceous planktic foraminiferal biostratigraphy; most of the subsequent reports of $W$. archaeocretacea are erroneous. In contrast, the taxonomic revision in evolutionary classification by Georgescu (2011) provided a sharp perspective on this taxon test morphology, wide range of morphological variability, stratigraphical range and evolutionary relationships.

- Comments (2). There is not known one planktic foraminiferal species to provide a bioevents that corresponds to the Cenomanian/Turonian boundary. The narrow Praeglobotruncana turbinata Biozone provides a relatively elevated level of accuracy of the interval that includes this boundary.

\section{Globotruncanita carpathica Biozone}

- Age. Early Turonian.

- Definition. Stratigraphical interval from the BKEO of the index species to the BKEO of Bucherina helvetica. 
- Type. Interval Biozone.

- Comments (1). This biozone comprises the upper part of the Whiteinella archaeocretacea Biozone of Robaszynski and Caron (1995) according to the original definition of Georgescu (2012), which is followed herein.

- Comments (2). Test morphology, range of variability, stratigraphical range and evolutionary relationships were reviewed in evolutionary classification by Georgescu (2012). The species Globotruncana marianosi of Douglas (1969) and Dicarinella elata of Lamolda (1977), which were and still are considered valid by various authors that use the Linnaean classification, are junior synonyms of the index species.

- Comments (3). The Marginotruncana marianosi Biozone described by Petrizzo (2000) is invalid for it is based on erroneously identified specimens of Concavatotruncana repanda, and this is confirmed further by the late Coniacian-earliest Santonian age of this biozone (Petrizzo, 2000), which stratigraphically is at a much higher level than that of the Globotruncanita carpathica Biozone.

\section{Bucherina helvetica Biozone}

- Age. Late early Turonian-early Middle Turonian.

- Definition. Stratigraphical interval between the BKEO and BKEX of Bucherina helvetica.

- Type. Taxon Range Biozone.

- Comments (1). This biozone defined by Sigal (1955) is one of the oldest and most stable biozone of Cretaceous planktic foraminifera. The index species presents plano-convex tests with hemispherical chambers on the umbilical side, one feature that makes it easily recognizable amongst the coeval taxa with strongly asymmetrical tests.

- Comments (2). Bucherina helvetica is the only index species of a biozone of this biostratigraphical framework, which was originally described from thin sections (Bolli, 1945).

\section{Hedbergella hoelzli Biozone}

- Age. Middle Turonian.

- Definition. Stratigraphical interval with the index species between the BKEX of Bucherina helvetica to the BKEO of Globotruncana cachensis.

- Type. Partial Taxon Range Biozone.

- Comments (1). The species name of the index species can be found in literature under two other variants: hölzli as originally given by Hagn and Zeil (1954) or hoelzli, which was used for the first time by Belford and Scheibnerová (1971).

- Comments (2). This biozone was defined by Georgescu and Heikkinen in Georgescu et al. (2013). The index species frequency varies significantly along its stratigraphical range; it is rare before the BKEX of Bucherina helvetica and most frequent within the biozone.

\section{Globotruncana cachensis Biozone}

- Age. Late Middle Turonian-early Late Turonian.

- Definition. Stratigraphical interval from the BKEO of the index species to the BKEO of Pseudoguembelina huberi.

- Type. Interval Biozone.
- Comments (1). The index species received several names following its description by Douglas in Douglas and Sliter (1966). The most frequently used is that of Falsotruncana maslakovae under which was described by Caron (1981). In fact, Caron (1981) validated three species of Falsotruncana differentiated especially by the degree of development of the two peripheral keels. The correct name of the taxon was reinstated after its revision in evolutionary classification by Georgescu and Heikkinen in Georgescu et al. (2013).

- Comments (2). The Globotruncana cachensis Biozone was defined by Douglas (1969) shortly after the index species description. In the absence of a solid documentation of the index species taxonomy and nomenclature history, the Falsotruncana maslakovae Biozone was defined and used rarely afterwards (Wonders, 1992; Petrizzo, 2000; Huber et al., 2017). This biostratigraphical unit was renamed Falsotruncana cachensis Biozone with the revision in evolutionary classification (Georgescu and Heikkinen in Georgescu et al., 2013).

\section{Pseudoguembelina huberi Biozone}

- Age. Late Turonian.

- Definition. Stratigraphical interval from the BKEO of the index species to the BKEO of Concavatotruncana concavata.

- Type. Interval Biozone.

- Comments (1). The potential use in biostratigraphy of the index species was prefigured by Georgescu et al. (2011), who noted its occurrence in the upper Turonian sediments and moreover, showed that there is a distinct prospect to use it in recognizing the Turonian/Coniacian boundary.

- Comments (2). Huber et al. (2017) defined the Marginotruncana sinuosa-Huberella huberi Biozone which is invalid: (a) Marginotruncana sinuosa is not a valid species, but a junior synonym of $M$. angusticarinata (Robaszynski et al., 1979; Eicher, 1982; Neagu, 1987); (b) there is a significant stratigraphical interval, which encompasses a duration of circa two million years, between the BKEO of the two designated index species: proximity of the lower/middle Turonian boundary in the case of $M$. angusticarinata and upper Turonian for H. huberi, and one biozone cannot have two lower boundaries.

\section{Concavatotruncana concavata Biozone}

- Age. Latest Turonian.

- Definition. From the BKEO of the index species to the BKEO of Concavatotruncana repanda.

- Type. Interval Biozone.

- Comments (1). The BKEO of the index species is situated before the Turonian/Coniacian boundary and this was recognized with the calibration by Robaszynski and Caron (1995).

- Comments (2). The Concavatotruncana concavata Biozone is retained herein in a narrower sense when compared to other zonations; it is restricted to the uppermost Turonian stage, whereas in other biostratigraphical frameworks encompasses the Coniacian and sometimes lower part of the Santonian. 


\section{Concavatotruncana repanda Biozone}

- Age. Early-early Middle Coniacian.

- Definition. Stratigraphical interval from the BKEO of the index species to the BKEO of Concavatotruncana asymetrica.

- Type. Interval Biozone.

- Comments (1). Globotruncana concavata cyrenaica was used as index species for the lower Coniacian stage in the same work in which it was described by Barr (1972); its role in biostratigraphy as marker for the Turonian/Coniacian boundary is acknowledged herein.

- Comments (2). The taxonomic status of this species suffered significant changes through time. Its intercontinental distribution was recognized under the name of Globotruncanita elevata "formas primitivas" under which was identified by Linares Rodríguez (1977) and subsequently reported by other authors (Neagu, 1987; Georgescu, 1996; Petrizzo, 2000). These tests were described independently and under distinct species names: Globotruncana repanda by Bolli (1957), $G$. dentata by Hooper (1977) and $G$. vescicarinata by Belford (1983). The species received different names even during the developments of evolutionary classification: vescicarinata at the time of description of the directional lineage Exmouthia by Georgescu in Georgescu et al. (2013) and dentata at the time of development of the practical nomenclature associated with the evolutionary classification. The oldest name is identified herein, with the mention that such a late recognition is probably due to the holotype of G. repanda that has fewer chambers in the final whorl when compared to most of the specimens assigned to the spcies. The case of this species nomenclature illustrates with clarity that sometimes the advances in taxonomy are slow and as a personal note, I found it the most difficult taxonomical problem to solve during the development of evolutionary classification.

\section{Concavatotruncana asymetrica Biozone}

- Age. Late Middle-early Late Coniacian.

- Definition. Stratigraphical interval between the BKEO of the index species and BKEO of Sigalia carpatica.

- Type. Interval Biozone.

- Comments (1). This biozone was used for the first time by Sigal (1955) under the name Globotruncana concavata Zone, and there is a confusion between the chosen index and another species J. Sigal described three years earlier as Globotruncana asymetrica.

- Comments (2). One name of the index species used often in the past was given after that of the species Globotruncana (Globotruncana) ventricosa carinata, which was described by Dalbiez (1955); this species is a junior synonym of $C$. asymetrica.

- Comments (3). The lower boundary of this biozone is within the Coniacian stage according to Lamolda et al. (2014), and this contrasts to the framework of Robaszynski and Caron (1995) where it is placed within the Santonian stage. The former idea prevails, since the lower boundary of the immediately higher Sigalia carpatica Biozone is within Coniacian.
Sigalia carpatica Biozone

- Age. Late Late Coniacian-Santonian (excepting the latest part).

- Definition. Stratigraphical interval between BKEO of the index species and BKEO of $S$. proliferans.

- Type. Interval Biozone.

- Comments (1). This biozone was described by Nederbragt (1990 fide Robaszynski and Caron, 1995).

- Comments (2). The evolution of the index species was a fast process, which helps in the accurate recognition of the biozone lower boundary (Nederbragt, 1991; Georgescu, 2010).

- Comments (3). Lamolda et al. (2014) demonstrated that the index species occurs below the Coniacian/Santonian boundary and this idea is followed herein. The lower boundary of this biozone is one of the cases in which the framework of Robaszynski and Caron (1995) had to be abandoned.

\section{Sigalia proliferans Biozone}

- Age. Latest Santonian.

- Definition. Stratigraphical interval between the BKEO of the index species and BKEX of C. asymetrica.

- Type. Interval Biozone.

- Comments. Sigalia proliferans is herein designated as index for the biozone that includes the upper part of the Santonian. Its BKEO separates the stratigraphical interval between the BKEO of $S$. carpatica and BKEX of $C$. asymetrica into two almost equal intervals; such a choice can be helpful in recognizing biozones within a stage in which the evolution of some planktic foraminiferal groups happened at a high rate.

\section{Ventilabrella alpina Biozone}

- Age. Early Early Campanian.

- Definition. Stratigraphical interval between the BKEX of C. asymetrica to the BKEX of the index species.

- Type. Interval Biozone.

- Comments. The index species of the Ventilabrella eggeri Biozone defined by Nederbragt (1990 fide Robaszynski and Caron, 1995) is herein renamed to accommodate the taxonomical changes induced by the review of the ventilabrellid planktic foraminifera in evolutionary classification (Georgescu, 2010). According to them $V$. eggeri is the oldest species of the genus from which two others evolved divergently: $V$. glabrata and $V$. alpina. This evolutionary framework contrasts to that provided by Nederbragt $(1990,1991)$, in which Ventilabrella was considered a monospecific genus including the species $V$. eggeri. Notably, the index species was reported by most authors as Ventilabrella browni that according to Georgescu (2010) is a junior synonym of $V$. alpina.

\section{Heterohelix reussi Biozone}

- Age. Late Early Campanian-early Middle Campanian.

- Definition. Stratigraphical interval with the index species between the BKEX of Ventilabrella alpina and BKEO of Globotruncana ventricosa.

- Type. Partial Taxon Range Biozone.

- Comments (1). The index species has a long stratigraphical range that begins in the upper Turonian with the evolution 
from Heterohelix mihaii as demonstrated by Georgescu in Georgescu et al. (2013). Heterohelix reussi cannot be confused for $H$. striata with which it co-occurs frequently throughout the Santonian-Maastrichtian stratigraphical interval; chamber growth rates, periapertural structures and ornamentation features of the two species show significant differences as shown by Georgescu (2013a).

- Comments (2). Nederbragt (1990 fide Robaszynski and Caron, 1995) defined two biozones based on species of the genus Pseudoguembelina within the stratigraphical interval encompassed herein by the Heterohelix reussi Biozone. The re-evaluation of the representatives of this genus (Georgescu, 2014d) showed that the transition from the oldest and finely costate pseudoguembelinids to those with coarser ornamentation happened earlier, namely above the Santonian/Campanian boundary. Therefore, there are no pseudoguembelinid markers within the upper Lower Campanian-Middle Campanian stratigraphical interval.

\section{Globotruncana ventricosa Biozone}

- Age. Middle Campanian-earliest Late Campanian.

- Definition. Stratigraphical interval from the BKEO of the index species to the BKEO of Radotruncana calcarata.

- Type. Interval Biozone.

- Comments (1). The biostratigraphical role of this species was first recognized by Dalbiez (1955) who defined the Globotruncana ventricosa Biozone.

- Comments (2). The lower boundary of this biozone was questioned by Wonders (1992) who noted that Globotruncana ventricosa occurs intermittently starting in the Santonian in the ODP boreholes from the Exmouth Plateau (762C and 763B); therefore, this author concluded that the occurrences from the higher stratigraphical levels in the Tethyan Realm are the result of subsequent colonization. This idea was followed by Petrizzo et al. (2011), who further removed the status of index species of $G$. ventricosa. The re-evaluation of this species in the evolutionary classification shows that $G$. ventricosa is the terminal species of the oldest stalk lineage that evolved globotruncanid morphology and began its evolution in the late Albian times. Plano-convex tests occur consistently only in $G$. ventricosa, but earlier species also present test varieties with plano-convex testshape that occur sporadically through their stratigraphical ranges; one of them was formalized as Marginotruncana paraventricosa by Hofker (1956). This is one case in which it is evident that the onset of a new feature did not happen suddenly and unsuccessful attempts to develop it can be documented at least in the immediate ancestor. Therefore, the index species status of $G$. ventricosa can be questioned only if test morphological features are not evaluated from an evolutionary perspective. Globotruncana ventricosa Biozone is herein considered valid and reinstated.

- Comments (3). Contusotruncana plummerae Biozone was proposed by Petrizzo et al. (2011) for the median portion of the Campanian stage, with the lower boundary defined by the alleged first occurrence of the index species. The evolution from $C$. bouldinensis to C. plummerae is mostly apparent in the test wall ultrastructure, namely from simple to simple-ridged and this transition can be observed with accuracy only with the aid of a scanning electron microscope. The evolutionary process happened in the proximity of the Santonian-Campanian boundary and well-preserved specimens of the $C$. plummerae are known from just above the Santonian/Campanian boundary. This is a stratigraphical level situated significantly below the alleged first occurrence on which the homonym biozone was defined; the time interval represented by the stratigraphical interval between the occurrence of $C$. plummerae and the lower boundary of the homonym biozone as defined by Petrizzo et al. (2011) is of circa four million years. Although incorporated in the Cretaceous chapter of The Geological Time Scale 2012 (Ogg and Hinnov, 2012), the C. plummerae Biozone is herein proved invalid.

\section{Radotruncana calcarata Biozone}

- Age. Early Late Campanian.

- Definition. Stratigraphical interval from the BKEO of the index species to the BKEO of Heterohelix rajagopalani.

- Type. Interval Biozone.

- Comments (1). The first report of this biozone by Sigal (1952) is vague and is herein interpreted as alluding to the total range of occurrence of Globotruncana calcarata. The occurrence of the index species was subsequently reported in the upper Campanian by many authors such as Reiss (1952), Van Hinte (1963), etc; the complete definition of the biozone is herein considered that given by Van Hinte (1965).

- Comments (2). As defined herein, the Radotruncana calcarata Biozone includes only the lower part of the total range of the nominal species, and this is the first attempt to refine what was considered in the past one of the narrowest biozones of Cretaceous planktics.

\section{Heterohelix rajagopalani Biozone}

- Age. Early Late Campanian.

- Definition. Stratigraphical interval from the BKEO of the index species to the BKEX of Radotruncana calcarata.

- Type. Interval Biozone.

- Comments (1). The BKEO of the index species is situated at about half of the stratigraphical range of $R$. calcarata, and this bioevents is used to define the biozone lower boundary.

- Comments (2). The evolution of Heterohelix rajagopalani from $H$. pseudotessera was a fast process apparent mostly in the ornamentation thickening and development of the central area between the two rows of divergent chambers (Georgescu et al., 2008).

\section{Praeglobotruncana havanensis Biozone}

- Age. Late Campanian.

- Definition. Stratigraphical interval with the index species between the BKEX of Radotruncana calcarata and BKEO of Bucherina gansseri.

- Type. Partial Taxon Range Biozone.

- Comments (1). The index species BKEO occurs in the middle Campanian and was well-documented by Masters (1977) who figured one specimen from the Demopolis Chalk of Alabama. 
- Comments (2). This biozone encompasses the combined stratigraphical ranges of Globotruncanella havanensis Biozone and Globotruncana aegyptiaca Biozone of Robaszynski and Caron (1995). The use of the Globotruncana aegyptiaca Biozone is avoided because of the confusion between G. aegyptiaca, G. ackermanni and G. gagnebini existing at the time of this biozone definition.

- Comments (3). One alternative index for this partial taxon range biozone is Praeglobotruncana subpetaloidea; such biozone was recognized in some DSDP/ODP boreholes of the Eastern Indian Ocean and Pacific Ocean, where in the original definitions was given as either Globotruncanella subpetaloidea or Abathomphalus subpetaloidea (Georgescu and Sawyer, 2013; Georgescu, 2014d). The definition of the Globotruncanella subpetaloidea Biozone is identical to that of the $P$. havanensis Biozone: stratigraphical interval with the index species between the BKEX of Radotruncana calcarata and BKEO of Bucherina gansseri. Therefore, this biozone can be also referred to as the Praeglobotruncana havanensis/P. subpetaloidea Biozone.

\section{Bucherina gansseri Biozone}

- Age. Latest Campanian.

- Definition. Stratigraphical interval between the BKEO of the index species and BKEO of Gublerina cuvillieri.

- Type. Interval Biozone.

- Comments (1). This biozone encompasses only the lower part of the stratigraphical interval of the homonym one accepted by Robaszynski and Caron (1995), where it is extended above the Campanian/Maastrichtian boundary.

- Comments (2). A gradual morphological ancestordescendant transition between Globotruncana pettersi and G. gansseri was mentioned by Gandolfi (1955).

\section{Gublerina cuvillieri Biozone}

- Age. Early Maastrichtian-early Late Maastrichtian.

- Definition. Stratigraphical interval between the BKEO of the index species and BKEO of Abathomphalus mayaroensis.

- Type. Interval Biozone.

- Comments (1). The occurrence of the index species is the result of a fast process of evolution that is morphologically apparent in the development of an adult stage with multichamber growth in Gublerina cuvillieri from the biserial throughout $H$. rajagopalani (Georgescu et al., 2008).

- Comments (2). Pseudoguembelina palpebra Biozone defined by Huber et al. (2008) is not accepted in this biostratigraphical framework mainly because its lower boundary can be practically defined anywhere along the morphological transition from Heterohelix prima to Pseudoguembelina palpebra, a process that happened during circa 1.5 million years and resulted in the occurrence of several test morphologies intermediary between the two species. Such a lack of precision in recognizing the evolution of the index species is apparent in how the lower boundary of this biozone was positioned: below the Campanian/Maastrichtian boundary in the original description and above by Ogg and Hinnov (2012) in The Geological Time Scale 2012.
- Comments (3). The biozones used in the last decades having the lower boundary defined by the lower occurrences of Racemiguembelina fructicosa, Contusotruncana contusa or both, are considered unusable in biostratigraphy; the lower boundaries of these biozones were defined in series of gradual morphological transitions, which lead to situations conceptually identical to the lower boundary of the Pseudoguembelina palpebra Biozone. Therefore, these biostratigraphical units are considered of low resolution and rejected for this reason.

\section{Abathomphalus mayaroensis Biozone}

- Age. Late Maastrichtian.

- Definition. Stratigraphical interval between the BKEO of the index species and BKEO of Ventilabrella hariaensis.

- Type. Interval Biozone.

- Comments (1). There is a gradual evolution from Abathomphalus intermedia to A. mayaroensis (Georgescu and Sawyer, 2013), but the development of the descendant's test morphology that can be used so accurately in defining the lower boundary of this biozone is given by the umbilical keel that reaches a peripheral position and is as well-developed as the dorsal keel.

- Comments (2). This biozone was for the first time recognized by Bolli (1957) and used without interruption ever since.

\section{Ventilabrella hariaensis Biozone}

- Age. Latest Maastrichtian.

- Definition. Stratigraphical interval between the BKEO and BKEX of the index species.

- Type. Taxon Range Biozone.

- Comments (1). This biozone was defined by Nederbragt (1990 fide Robaszynski and Caron, 1995) and used frequently afterwards by many authors. Its upper boundary is marked by the mass extinction event that led to the disappearance of the vast majority of Cretaceous planktics (Loeblich and Tappan, 1957).

- Comments (2). Evolution from Pseudoguembelina palpebra to Ventilabrella hariaensis is a fast process that results in the loss of the supplementary apertures from the proximity of the central suture on the lastformed chambers, and evolution of an adult stage with multichamber growth (Georgescu, 2014a, d).

\section{CONCLUSIONS}

There is an evident increase in the resolution of the biostratigraphical zonations developed in more than six decades (Fig. 7); the increase was in general slow, with two abrupt rises in the number of used biozones (Bolli, 1966; Van Hinte, 1976). The first biostratigraphical frameworks based on units of the practical classification associated with the evolutionary classification shows a significant step forward in increasing the zonation accuracy. Twenty-four biozones are recognized, an increase of over $25 \%$ when compared with the highest accuracy based on Linnaean units, which is that of The Geological Time Scale 2012 that consists of nineteen biozones. An average of 1.4 million years for one biochronozone is achieved for the whole Late Cretaceous, for the first time this value dropping below 1.5 million years per biozone. 


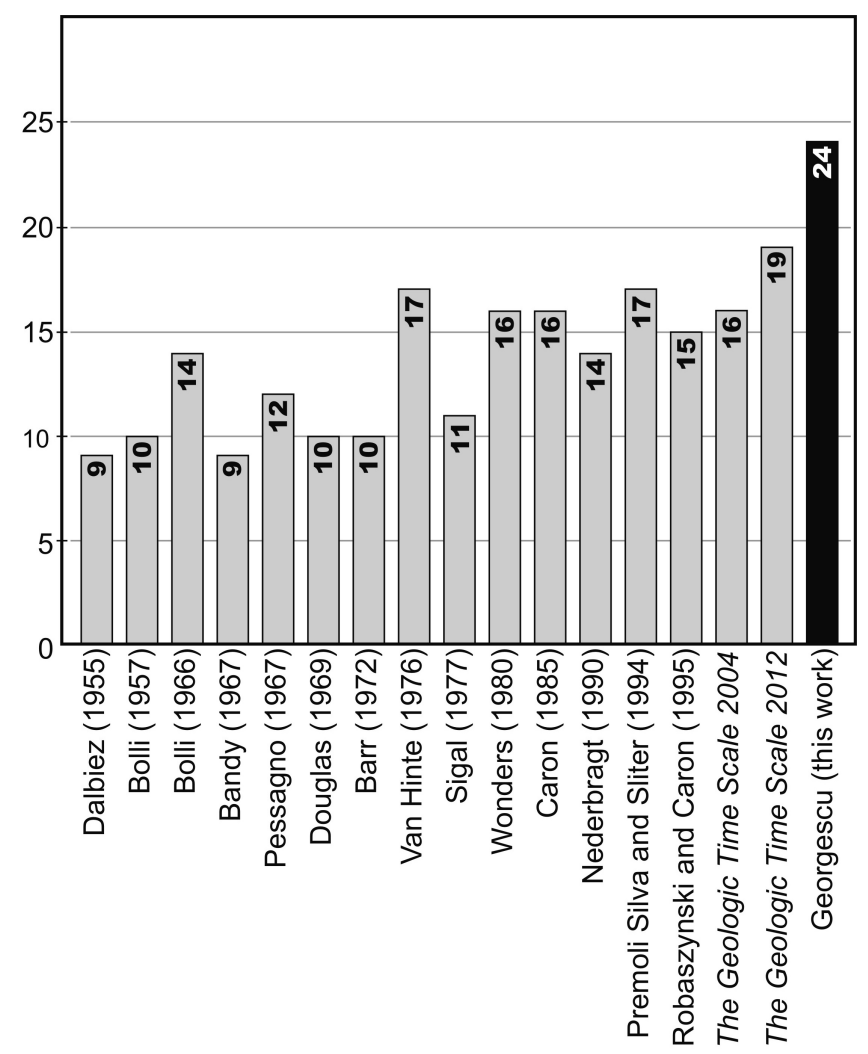

Fig. 7. The number of recognized biozones in different biostratigraphical frameworks based on Late Cretaceous planktic foraminifera. Those that use Linnaean classification units are given as grey columns, whereas that in which the index taxa are derived from evolutionary classification as black column.

The accuracy increase is generated partly by the influx of index species from the heterohelicid group, which was the subject of extensive studies in evolutionary classification in the last decade. Only the Coniacian Stage does not include biozones that have heterohelicid index species. Integrating data and biozones defined by species from a different planktic foraminiferal group can represent one leading stream in the further advances in the Upper Cretaceous biostratigraphy based on planktic foraminifera. Notably, this trend continues the pioneering work of Nederbragt (1990 fide Robaszynski and Caron, 1995) who provided a biostratigraphical framework for the Upper Cretaceous consisting entirely of heterohelicidbased biozones.

Implementation of the recent advances in evolutionary classification into biostratigraphy answers at least partly the question on how data provided by the Theory of Evolution should be transferred to applied studies. This present attempt is through a loss of resolution resulted from the transition from the stages of morphological relative stability of the evolutionary classification to the species of the practical classification associated with it. However, this is only the first development of the method for which additional strategies can be further designed and pursued.

\section{REFERENCES}

Bandy, O.L., 1951, Upper Cretaceous foraminifera from the Carlsbad area, San Diego County, California. Journal of Paleontology, 25: 488-513.

http://www.jstor.org/stable/1299747
Barr, F.T., 1972, Cretaceous biostratigraphy and planktonic foraminifera of Libya. Micropaleontology, 18: 1-46. http://www.jstor.org/stable/1484977

Belford, D.J., 1983, A probable Coniacian (Late Cretaceous) foraminiferal fauna, Carnarvon Basin, Western Australia. Bulletin of the Bureau of Mineral Resources, Geology and Geophysics, 217: 11-27.

Belford, D.J., Scheibnerová, V., 1971, Turonian foraminifera from the Carnarvon Basin, Western Australia, and their palaeogeographical significance. Micropaleontology, 17: 331-344.

http://www.jstor.org/stable/1485144

Bolli, H., 1945, Zur Stratigraphie der Oberen Kreide in den höheren helvetischen Decken. Eclogae Geologicae Helvetiae, 37: 217-329.

Bolli, H., 1951, The genus Globotruncana in Trinidad, B.W.I. Journal of Paleontology, 25: 187-199. http://www.jstor.org/stable/1299798

Bolli, H., 1957, The genera Praeglobotruncana, Rotalipora, Globotruncana, and Abathomphalus in the Upper Cretaceous of Trinidad, B.W.I. In Studies in Foraminifera (Loeblich, A.R. Jr., Ed.). United States National Museum Bulletin, 215: 51-60.

Bolli, H., 1960, Planktonic foraminifera as index fossils in Trinidad, West Indies and their value for worldwide stratigraphic correlation. Eclogae Geologicae Helvetiae, 52: 627-637.

Bolli, H., 1966, Zonation of Cretaceous to Pliocene marine sediments based on planktonic foraminifera. Boletín Informativo Associatión Venezolana de Geología, Mineria y Petróleo, 9: 3-32.

Brönnimann, P., 1952, Globigerinidae from the Upper Cretaceous (Cenomanian-Maestrichtian) of Trinidad, B.W.I. Bulletins of American Paleontology, 34 (140): 5-70.

Brönnimann, P., Brown, N.K. Jr., 1956, Taxonomy of Globotruncanidae. Eclogae Geologicae Helvetiae, 48: 503-561.

Caron, M., 1976, Révision des types de Foraminifères planctoniques décrits dans la region du Montsalvens (Préalpes fribourgeoises). Eclogae Geologicae Helvetiae, 69: 327-333.

Caron, M., 1985, Cretaceous planktic foraminifera. In Plankton Stratigraphy (Bolli, H.M., Saunders, J.B., PerchNielsen, K., Eds.). Cambridge University Press, Cambridge, p. 17-86.

Caron, M., 1981, Un nouveau genre de foraminifère planctoniques du Crétacé: Falsotruncana nov. gen. Eclogae Geologicae Helvetiae, 74: 65-73.

Caron, M., Spezzaferri, S., 2006, Scanning electron microscope documentation of the lost holotypes of Mornod, 1949: Thalmanninella reicheli and Rotalipora montsalvensis. Journal of Foraminiferal Research, 36: 374-378. https://doi.org/10.2113/gsjfr.36.4.374

Dalbiez, F., 1955, The genus Globotruncana in Tunisia. Micropaleontology, 1: 161-171.

http://www.jstor.org/stable/1484170

Darwin, C., 1859, On the Origin of Species by Means of Natural Selection, or the Preservation of Favoured Races in the Struggle for Life. John Murray, London, 502 p. 
Douglas, R.G., 1969, Upper Cretaceous planktonic foraminifera in northern California. Part 1, Systematics. Micropaleontology, 15: 151-209. http://www.jstor.org/stable/1484919

Douglas, R.G., Sliter, W.V., 1966, Regional distribution of some Cretaceous Rotaliporidae and Globotruncanidae (Foraminiferida) within North America. Tulane Studies in Geology, 4: 89-131.

https://library.tulane.edu/journals/index.php/tsgp/ article/view/423

Ehrenberg, C.G., 1838, Über die Bildung der Kreidefelsen und des Kreidemergels durch unsichtbare Organismen. Abhandlungen der Königlichen Akademie der Wissenschaften zu Berlin, 1838: 59-147 (published in 1839).

Eicher, D.L., 1982, Review. Micropaleontology, 28: 93-96. http://www.jstor.org/stable/1485363

Eldredge, N., Gould, S.J., 1972, Punctuated equlibria: An alternative to phyletic gradualism. In Models in Paleobiology (Schopf, T.J.M., Ed.). Freeman, Cooper and Co, San Francisco, p. 82-115.

Gandolfi, R., 1955, The genus Globotruncana in northeastern Colombia. Bulletins of American Paleontology, 36 (155): 7-118.

Georgescu, M.D., 1995, Upper Cretaceous Heterohelicidae in the Romanian Western Black Sea offshore. Revista Española de Micropaleontología, 27: 91-106.

Georgescu, M.D., 1996, Santonian-Maastrichtian planktonic foraminifers (Globigerinelloididae, Hedbergellidae, Globotruncanidae and Rugoglobigerinidae) in the Romanian Black Sea offshore. Micropaleontology, 42: 305-333. http://www.jstor.org/stable/1485955

Georgescu, M.D., 2000, Late Albian-Turonian planktonic foraminifera in the Romanian Western Black Sea offshore. Revista Española de Micropaleontología, 32: 157-173.

Georgescu, M.D., 2003, Microfaunal abundance and basinal evolution of the Western Black Sea (Romanian offshore, Cretaceous to Pliocene). In Micropaleontologic Proxies to Sea Level Changes (Olson, H., Leckie, R.M., Eds). The Society of Economical Paleontologists and Mineralogists, Special Publication, 75: 301-315.

https://doi.org/10.2110/pec.03.75.0301

Georgescu, M.D., 2006, Santonian-Campanian planktonic foraminifera in the New Jersey coastal plain and their distribution related to the relative sea-level cycles. Canadian Journal of Earth Sciences, 43: 101-120.

https://doi.org/10.1139/e05-090

Georgescu, M.D., 2007a, Taxonomic re-evaluation of the late Cretaceous serial planktonic foraminifer Gümbelina punctulata Cushman, 1938 and related species. Revista Española de Micropaleontologia, 39: 155-167.

Georgescu, M.D., 2007b, A new planktonic foraminiferal genus from the Upper Cretaceous (Turonian). Micropaleontology, 53 (3): 212-220.

https://doi.org/10.2113/gsmicropal.53.3.212

Georgescu, M.D., 2009a, Taxonomic revision and evolutionary classification of the biserial Cretaceous planktic foraminiferal genus Laeviheterohelix Nederbragt, 1991. Revista Mexicana de Ciencias Geológicas, 26 (2): 315-334. http://scielo.unam.mx/pdf/rmcg/v26n2/v26n2a4.pdf
Georgescu, M.D., 2009b, Transition from the typological to evolutionary classification of the Cretaceous planktic foraminifera: case study of Anaticinella Eicher 1973. Micropaleontology, 55: 589-616.

http://www.jstor.org/stable/40607070

Georgescu, M.D., 2009c, Upper Albian-lower Turonian nonschackoinid planktic foraminifera with elongate chambers: morphology reevaluation, taxonomy and evolutionary classification. Revista Española de Micropaleontología, 41: 255-293.

Georgescu, M.D., 2010, Origin, taxonomic revision and evolutionary classification of the late Coniacian-early Campanian (Late Cretaceous) planktic foraminifera with multichamber growth in the adult stage. Revista Española de Micropaleontología, 42: 59-118.

Georgescu, M.D., 2011, Iterative evolution, taxonomic revision and evolutionary classification of the praeglobotruncanid planktic foraminifera, Cretaceous (late Albian-Santonian). Revista Española de Micropaleontología, 43: 173-207 (Published in 2012).

Georgescu, M.D., 2012a, Morphology, taxonomy, stratigraphic distribution and evolutionary classification of the schackoinid planktic foraminifera (late AlbianMaastrichtian, Cretaceous). In Deep-sea marine biology, geology, and human impact (Bailey, D.R., Howard, S.E., Eds.). Nova Publishers, New York, p. 1-62.

https://www.novapublishers.com/catalog/product info. php?products id $=31491 \& \cos C \operatorname{sid}=14 \mathrm{~b} 2589 \mathrm{fd} 07468696176$ $1 \mathrm{e} 78 \mathrm{c} 959 \mathrm{a} 2 \mathrm{a} 4$

Georgescu, M.D., 2012b, Origin, evolutionary classification, and biostratigraphic significance of the Late Cretaceous planktic foraminiferal directional lineage Bollitruncana O.A. Korchagin, 2001. Studia UBB Geologia, 57: 1-16. https://doi.org/10.5038/1937-8602.57.2.1

Georgescu, M.D., 2013a, Revised evolutionary systematics of the Cretaceous planktic foraminifera described by C.G. Ehrenberg. Micropaleontology, 59: 1-49.

http://www.jstor.org/stable/24413314

Georgescu, M.D., 2013b, Cretaceous planktic foraminifera from the Jacob Whitman Bailey Collection (Farlow Herbarium, Harvard University). In Foraminifera. Aspects of classification, stratigraphy, ecology and evolution (Georgescu, M.D., Ed.). Nova Science Publishers, New York, p. 101-118.

Georgescu, M.D., 2014a, Evolutionary classification and nomenclature of the Cretaceous planktic foraminifera with the chambers alternately added with respect to the test growth axis. In: Evolutionary classification and Englishbased Nomenclature in Cretaceous Planktic Foraminifera (Georgescu, M.D., Henderson, C.M., Eds.). Nova Science Publishers, New York, p. 129-248.

Georgescu, M.D., 2014b, Evolution of central perforate plate in the new condensed lineage Eicheriella. In Evolutionary classification and English-based Nomenclature in Cretaceous Planktic Foraminifera (Georgescu, M.D., Henderson, C.M., Eds.). Nova Science Publishers, New York, p. 93-100. 
Georgescu, M.D., 2014c, Reinstatement of the Cretaceous planktic foraminifer Bronnimannella Montanaro Gallitelli 1956 as directional lineage in evolutionary classification. In Evolutionary classification and English-based Nomenclature in Cretaceous Planktic Foraminifera (Georgescu, M.D., Henderson, C.M., Eds). Nova Science Publishers, New York, p. 27-38.

Georgescu, M.D., 2014d, New Late Cretaceous (SantonianMaastrichtian) heterohelicid planktic foraminifera from the Pacific and Indian Oceans and their biostratigraphic and evolutionary significance. In Evolutionary classification and English-based Nomenclature in Cretaceous Planktic Foraminifera (Georgescu, M.D., Henderson, C.M., Eds). Nova Science Publishers, New York, p. 39-71.

Georgescu, M.D., 2015, Handbook of late Cretaceous Planktic Foraminifera (Practical classification, biostratigraphy). Nova Science Publishing, New York, 331 p.

Georgescu, M.D., 2016, Evolutionary classification of rotaliporid planktic foraminifera. An evolutionary monograph. Lambert Academic Publishing, Saarbrucken, $266 \mathrm{p}$.

Georgescu, M.D., Quinney, A.E. \& Anderson, K.D., 2011, New data on the taxonomy, evolution and biostratigraphical significance of the Turonian-Coniacian (Late Cretaceous) planktic foraminifer Huberella Georgescu 2007. Micropaleontology, 57: 247-254.

http://www.jstor.org/stable/41410985

Georgescu, M.D., Saupe, E.E. \& Huber, B.T., 2008. Morphometric and stratophenetic basis for phylogeny and taxonomy in Late Cretaceous gublerinid planktonic foraminifera. Micropaleontology, 54: 397-424.

http://www.jstor.org/stable/30130916

Georgescu, M.D., Sawyer, M.S., 2013, Evolutionary classification of the globotruncanellid and abathomphalid planktic foraminifera (Late Cretaceous, late CampanianMaastrichtian). In Foraminifera: classification, biology, and evolutionary significance (Georgescu, M.D., Ed.). Nova Science Publishing, New York, p. 119-162.

Georgescu, M.D., Sawyer, M.S., Heikkinen, C.J. \& Burke, R.M., 2013, New and revised Cretaceous (AlbianCampanian) planktic foraminifera of the Atlantic, Indian and Pacific Oceans. In Foraminifera: classification, biology, and evolutionary significance (Georgescu, M.D., Ed.). Nova Science Publishing, New York, p. 59-100.

Hagn, H., Zeil, W., 1954, Globotruncanen aus dem OberCenoman und Unter-Turon der Bayerischen Alpen. Eclogae Geologicae Helvetiae, 47: 1-60.

Hay, W.H., DeConto, R.M., Wold, C.N., Wilson, K.M., Voigt, S., Schulz, M., Wold, A.R., Dullo, W, Ronov, A.B., Balukhovsky, A.N. \& Söding, E., 1999, Alternative global Cretaceous paleogeography. In Evolution of the Cretaceous Ocean-Climate System (Barrera, E., Johnson, C.C., Eds.). The Geological Society of America Special Publication, 332: 1-47.

https://doi.org/10.1130/0-8137-2332-9.1

Hitchcock, E., 1843, Notes on the Geology of several parts of Western Asia: founded chiefly on Specimens and Descriptions from American Missionaries. In Reports of the first, second, and third meetings of the association of
American Geologists and Naturalists at Philadelphia, in 1840 and 1841, and 1842 in Boston (Rogers, H.D., Beck, L.C., Silliman, R. Jr., Binney, A., Gould, A.A., Eds.). Gould, Kendall and Lincoln, Boston, p. 348-421.

Hofker, J., 1956, Die Globotruncanen von NordwestDeutschland und Holland. Neues Jahrbuch für Geologie und Paläontologie, Abhandlungen, 103: 312-340.

Hooper, K., 1977, Globotruncana dentata, a new species of planktonic foraminifer from the Toolonga Calcilutite of Western Australia. Micropaleontology, 23: 361-364. http://www.jstor.org/stable/1485221

Huber, B.T., MacLeod, K.G. \& Tur, N.A., 2008, Chronostratigraphic framework for Upper CampanianMaastrichtian sediments on the Blake Nose (subtropical North Atlantic). Journal of Foraminiferal Research, 38: 162-182.

https://doi.org/10.2113/gsjfr.38.2.162

Huber, B.T., Petrizzo, M.R., Watkins, D.K., Haynes, S.J. \& MacLeod, K.G., 2017, Correlation of Turonian continental margin and deep-sea sequences in the subtropical Indian Ocean sediments by integrated planktonic foraminiferal and calcareous nannofossil biostratigraphy. Newsletters on Stratigraphy, 50 (2): 141-185. https://doi.org/10.1127/nos/2017/0373

Kieser, J.A., Groencveld, H.T., 1985, A threshold model for punctuated gradualism. Medical Hypotheses, 17: 219-225. https://doi.org/10.1016/0306-9877(85)90126-4

Korchagin, O.A., 2003, Classification of the Mesozoic planktonic foraminifera (superfamilies Planomalinacea, Rotaliporacea and Globotruncanacea). Trudy VNIGRI, 547: 1-89 (In Russian).

Lamolda, M.A., 1977, Los Marginotruncaninae del Turoniense Vasco-Cantabrico. Revista Española de Micropaleontología, 9: 381-410.

Lamolda, M.A., Paul, C.R.C., Peryt, D. \& Pons, J.M., 2014, The Global Boundary Stratotype and Section Point (GSSP) for the base of the Santonian Stage, "Cantera de Margas", Olazagutia, northern Spain. Episodes, 37: 1-13. http://52.172.159.94/index.php/epi/article/view/57358

Linares Rodríguez, D., 1977, Foraminiferos planctonicos del Cretacico superior de las Cordilleras Beticas (sector central). Universidad de Málaga, Departamento de Geología, 410 p.

Lipson-Benitah, S., 2008, Phylogeny of the Middle Cretaceous (late Albian-late Cenomanian) planktonic foraminiferal genera Parathalmanninella nov.gen. and Thalmanninella. Journal of Foraminiferal Research, 38: 183-189. https://doi.org/10.2113/gsjfr.38.2.183

Loeblich, A.R. Jr., Tappan, H., 1957, Correlation of the Gulf and Atlantic Coastal Plain Paleocene and Lower Eocene formations by means of planktonic foraminifera. Journal of Paleontology, 31: 1109-1137.

http://www.jstor.org/stable/1300498

Loeblich, A.R. Jr., Tappan, H., 1987, Foraminiferal Genera and Their Classification. Van Nostrand Reinhold Company, New York, 970 p.

Mayr, E., 1968, Theory of biological classification. Nature, 220: $545-548$

https://doi.org/10.1038/220545a 0 
Mayr, E., Ashlock, P.D., 1991, Principles of systematic zoology. McGraw-Hill, New York, 475 p.

Mornod, L., 1949, Les Globorotalidés du Crétacé supérieur du Montsalvens (Prealpes fribourgeoises). Eclogae Geologicae Helvetiae, 42: 573-596 (Published in 1950).

Neagu, T., 1987, White chalk foraminiferal fauna in southern Dobrogea (Romania). 1. Planktonic foraminifera. Revista Española de Micropaleontología, 19: 281-314.

Neagu, T., 2005, Albian foraminifera of the Romanian Plain. Planktonic foraminifera. Acta Palaeontologica Romaniae, 5: 311-332.

http://www.geo-paleontologica.org/page7/Neagu pdf.pdf

Nederbragt, A.J., 1991, Late Cretaceous biostratigraphy and development of Heterohelicidae (planktic foraminifera). Micropaleontology, 37: 329-372. http://www.jstor.org/stable/1485910

Ogg, J.G., Agterberg, F.P. \& Gradstein, F.M., 2004, The Cretaceous Period. In The geologic time scale 2004 (Gradstein, F.M., Ogg, J.G., Smith, A.G., Eds.). Cambridge University Press, Cambridge, p. 344-383.

Ogg, J.G., Hinnov, L.A., 2012, Cretaceous. In The geologic time scale 2012 (Gradstein, F.M., Ogg, J.G., Schmitz, M., Ogg, G., Eds.). Elsevier, p. 793-853.

Pessagno, E.A. Jr., 1967, Upper Cretaceous planktonic foraminifera from the Western Gulf coastal plain. Palaeontographica Americana, 5 (37): 243-445.

Petrizzo, M.R., 2000, Upper Turonian-lower Campanian foraminifera from southern mid-high latitudes (Exmouth Plateau, NW Australia): biostratigraphy and taxonomic notes. Cretaceous Research, 21: 479-505. https://doi.org/10.1006/cres.2000.0218

Petrizzo, M.R., Falzoni, F. \& Premoli Silva, I., 2011, Identification of the base of the lower-to-middle Campanian Globotruncana ventricosa Zone: Comments on reliability and global correlations. Cretaceous Research, 32: 387-405. https://doi.org/10.1016/j.cretres.2011.01.010

Premoli Silva, I., Sliter, W.V., 1994, Cretaceous planktonic foraminiferal biostratigraphy and evolutionary trends from the Bottaccione section, Gubbio, Italy. Palaeontographia Italica, 82: 1-89.

Reiss, Z., 1952, On the occurrence of Globotruncana calcarata Cushman 1927 in the Upper Cretaceous of Israel. Bulletin of the Research Council of Israel, 2G/3: 270-272.

Robaszynski, F., Caron, M., 1995, Foraminifères planctoniques du Crétacé: commentaire de la zonation EuropeMèditerranée. Bulletin de la Société Géologique de France, 6: 681-692.
Robaszynski, F., Caron, M., González Donoso, J.M., Wonders, A.A.H. \& The European Working Group on Planktonic Foraminifera, 1984, Atlas of Late Cretaceous globotruncanids. Revue de Micropaléontologie, 26: 145-305.

Robaszynski, F., Caron, M. \& The European Working Group on Planktonic Foraminifera, 1979, Atlas de Foraminifères planctoniques du Crétacé moyen (Mer Boréale et Téthys). Cahiers de Micropaléontologie, 1: 1-185.

Sacal, V., Debourle, A., 1957, Foraminifères d'Aquitaine $2^{\mathrm{e}}$ partie. Peneroplidae a Victoriellidae. Mémoires de la Société Géologique de France, 78: 1-87.

Sigal, J., 1952, Aperçu stratigraphique sur la micropaléontologie du Crétacé. Alger, $19^{\text {th }}$ International Geological Congress, Monographies régionales, $1^{\text {re }}$ série, Algerie, 26: 1-52.

Sigal, J., 1955, Notes micropaléontologiques nord-africaines. 1. Du Cénomanien au Santonien: zones et limites en faciès pélagique. Compte Rendu Sommaire des Séances de la Société Géologique de France, 7-8: 157-160.

Van Hinte, J., 1963, Zur Stratigraphie und Mikropaläontologie der Oberkreide und des Eozäns des Krappfeldes (Kränten). Jahrbuch der Geologischen Bundesanstalt, 8: 1-147.

Van Hinte, J., 1965, The type Campanian and its planktonic Foraminifera. Proceedings of the Koninklijke Nederlandse Akademie van Wetenschappen, 68: 8-28.

Van Hinte, J., 1976, A Cretaceous time scale. The American Association of Petroleum Geologists Bulletin, 60: 498-516. https://doi.org/10.1306\%2F83D923ED-16C7-11D7$\underline{8645000102 \mathrm{C} 1865 \mathrm{D}}$

Weller, J.M., 1949, Paleontologic classification. Journal of Paleontology, 23: 680-690.

http://www.jstor.org/stable/1299677

Wonders, A.A.H., 1980, Middle and Late Cretaceous planktonic foraminifera of the Western Mediterranean area. Utrecht Micropaleontological Bulletin, 24: 1-157.

Wonders, A.A.H., 1992, Cretaceous planktonic foraminiferal biostratigraphy, Leg 122, Exmouth Plateau, Australia. In Proceedings of the ocean drilling program, scientific results Leg 122 (Haq, B.U., von Rad, U. et al., Eds.). Ocean Drilling Program, College Station, p. 587-599.

https://doi.org/10.2973/odp.proc.sr.122.160.1992

Wright, C.W., 1950, Paleontologic classification. Journal of Paleontology, 24: 746-748. http://www.jstor.org/stable/1299975

Young, K., 1960, Biostratigraphy and the new paleontology. Journal of Paleontology, 34: 347-358. http://www.jstor.org/stable/1300981 